\title{
Kualitas Simplisia Tanaman Biofarmaka Curcuma domestica Setelah Proses Pemanasan Pada Suhu Dan Waktu Bervariasi
}

\author{
Hermin Pancasakti Kusumaningrum*1) ${ }^{1)}$ Endang Kusdiyantini ${ }^{2)}$ dan Sri Pujiyanto ${ }^{3)}$ \\ 1), Laboratorium Genetika, Jurusan Biologi FSM, Universitas Diponegoro, Jl. Prof. Soedarto, UNDIP, Tembalang, \\ Semarang. 50275. Email herminsakti@gmail.com \\ ${ }^{2)}$ Laboratorium Biokimia, Jurusan Biologi FSM, Universitas Diponegoro, Jl. Prof. Soedarto, UNDIP, Tembalang, \\ Semarang. 50275. Email kusdiyantini@undip.ac.id \\ 3) Laboratorium Mikrobiologi, Jurusan Biologi FSM, Universitas Diponegoro, Jl. Prof. Soedarto, UNDIP, \\ Tembalang, Semarang. 50275. Email spujiyanto@ hotmail.com
}

\begin{abstract}
Curcuma domestica is one of traditional medicinal plants that is found in Gunungpati Semarang. However the dried product do not achieve optimal standard quality for simplicia in terms of microbial contaminant and in an industrial scale household. Knowledge on how to use sterilization to produce better simplicia and reducing contaminant has not been known by farmers, yet. The purpose of this activity was to obtain the best heating treatment on sterilization of Curcuma simplicia using several temperature under sunlight and oven device. It was also want to show microbial growth after heating at several times and their influence on the quality of simplicia after treatment. The method was conducted by simplicia sterilization of $\mathrm{C}$. domestica using sunlight sterilization for a week and using oven at a temperature of $30^{\circ} \mathrm{C}, 40^{\circ} \mathrm{C}, 50^{\circ} \mathrm{C}$ and $60^{\circ} \mathrm{C}$ for $1,3,6,9,12,24$, and 48 hours. The results showed that heating at temperature of $50^{\circ} \mathrm{C}$ for 48 hours obtained the best simplicia, followed by heating at a temperature of $60^{\circ} \mathrm{C}$ for $16-48$ hours without contaminants after storing period for 3 months.
\end{abstract}

Key words :Curcuma, sterilization, heat, microbia

\section{PENDAHULUAN}

Indonesia sangat kaya dengan berbagai ragam tanaman obat atau obat. Saat ini industri tanaman obat tradisional telah berkembang pesat di Indonesia. Kunyit atau kunir (Curcuma longa Linn. syn. Curcuma domestica Val.), adalah salah satu tanaman biofarmaka anggota famili Zingiberaceae yang berasal dari Asia Tenggara yang tersebar ke Malaysia, Indonesia, Australia dan Afrika. C. longa merupakan tanaman yang mempunyai kemampuan sebagai anti mikroba, anti oksidan, anti jamur dan anti inflamasi (Ferreira et al., 2013). Rimpang kunyit mengandung minyak asiri dengan senyawanya antara lain fellandrene, sabinene, sineol, borneol, zingiberene, curcumene, turmeron, kamfene, kamfor, seskuiterpene, asam kafrilat, asam methoksisinamat, tolilmetil karbinol. Selain itu rimpang kunyit juga mengandung tepung dan zat warna yang mengandung alkaloid kurkumin (Mateblowski, 1991). Senyawa aktif kunyit terdiri dari kurkumin (1,7-bis(4-hidroksi-3metoksifenil)-1E,6Eheptadiene-3,5-dione atau diferuloyl metan), thiosianat, nitrat, klorida dan sulfat, pati dan tanin, saponin, terpenoid, polipeptida dan lektin. Kurkumin merupakan obat yang dapat digunakan pada penyakit diabetes dan gagal ginjal (Trujillo et al., 2013), kanker, sakit perut (Kösslera et al., 2012), epilepsi, stress dan gangguan kognisi (Ahmad, 2013).

Penyiapan kunyit sebagai produk terstandar patut diperhatikan dan dicermati. Jika penanganan ataupun pengolahannya tidak benar maka mutu produk yang dihasilkan kurang berkhasiat atau kemungkinan dapat menimbulkan toksin apabila dikonsumsi. Toksin yang dihasilkan oleh mikrobia biasanya berasal dari jamur dikenal sebagai mikotoksin sebagai produk metabolit sekunder. Jamur yang biasa mendominasi produk pertanian adalah Aspergillus, Fusarium dan Penicillium (Ferreira et al., 2013). Standar nasional Indonesia untuk tanaman obat dijumpai pada tanaman kencur (Badan Standardisasi Nasional, 2005). Pada standar tersebut khamir dan kapang yang 
diperkenankan sejumlah $1 \times 10^{4}, \quad$ sedangkan mikroba patogen harus negatif.

Kegiatan Pengabdian masyarakat yang telah dilakukan adalah merancang alat sterilisasi portable berbasis teknologi Accumulated Sunlight Sterilization yang memadukan kemampuan sterilisasi cahaya, listrik, lampu dan gas serta bersifat mobile yang diaplikasikan untuk pengeringan tanaman obat bagi masyarakat Gunungpati. Sterilisasi merupakan proses yang sangat mendasar dalam mempersiapkan bahan tanaman obat atau obat herbal berkualitas dan terstandar agar tidak dijumpai mikroorganisme yang berbahaya, lebih higienis dan aman untuk dikonsumsi. Dibandingkan dengan beberapa metode yang biasa dilakukan di laboratorium maka metode sterilisasi yang paling tepat untuk mengurangi kontaminan sekaligus meningkatkan produk dan kualitas tanaman obat adalah dengan pengeringan. Pengeringan yang biasa dilakukan oleh petani tanaman obat adalah menggunakan sinar matahari langsung. Permasalahannya penggunaan cahaya matahari secara langsung mempunyai cukup banyak kelemahan antara lain kontaminasi, membutuhkan waktu yang lama yaitu lebih dari satu minggu, pemanasan yang tidak teratur akibat suhu yang naik turun dan tidak terkontrol, panas yang tidak kontinyu saat malam hari atau hari hujan, dan penurunan kualitas bahan atau produk tanaman obat. Selain itu masyarakat Gunungpati sebagai salah satu produsen tanaman obat tertinggi di Semarang kurang memiliki pengetahuan tentang cara memproses bahan tanaman obat yang baik sehingga lebih terhindar dari kontaminan pada proses penyiapan maupun penyimpanan.

Penggunaan ruang sterilisasi yang menggunakan kombinasi penggunaan sinar matahari secara langsung dengan blower, lampu, dan termostat selain akan membantu akumulasi dan sustainabilitas cahaya juga kontrol suhu yang baik akan menghasilkan produk yang lebih steril, banyak, dan optimal. Kelebihan teknologi ini adalah produk lebih steril, waktu pengeringan lebih cepat yaitu sekitar 6 - 8 jam, tempat tertutup, dan lebih higienis. Selain itu suhu dapat diatur untuk pengeringan bahan obat yang optimal yaitu suhu $40-60^{\circ} \mathrm{C}$ supaya kadar air tercapai $\pm 8-$ $10 \%$. Pengeringan yang tidak tepat akan menimbulkan beberapa akibat yaitu menimbulkan perubahan produk karena hidrolisis oleh enzim, pencokelatan, fermentasi dan oksidasi (Ahmad, 2013). Sterilisasi tanaman obat diawali sejak proses penyiapan tanaman obat, pengolahan sampai pengemasan. Tujuan dari kegiatan ini adalah untuk memperoleh perlakuan sterilisasi menggunakan pemanasan sinar matahari dan oven yang menghasilkan kualitas simplisia kunyit terbaik. Pemanasan dengan oven dilakukan menggunakan variasi suhu dan waktu. Selain itu juga ingin dilihat pertumbuhan mikrobia pada simplisia setelah proses pemanasan untuk melihat pengaruh proses pemanasan terhadap kualitas simplisia kunyit.

\section{BAHAN DAN METODE}

Kegiatan dilakukan melalui beberapa tahap. Tahap pertama adalah pemilihan bahan baku. Bahan dalam pembuatan simplisia kunyit adalah rimpang kunyit dari daerah Gunungpati dari hasil panen. Rimpang diambil yang berukuran besar dan berumur 9 - 12 bulan, segar dan tidak busuk. Tahap kedua adalah melakukan pencucian simplisia untuk menghilangkan kotoran dan mengurangi mikroba yang menempel pada rimpang kunyit. Pencucian dilakukan beberapa kali.

Tahap berikutnya adalah penimbangan bahan dilakukan pada tahap awal untuk mengetahui bobot bahan yang akan digunakan. Selanjutnya dilakukan perajangan secara membujur ataupun melintang. Perajangan dilakukan untuk memperoleh ketebalan yang memudahkan proses pengeringan dan seragam. Pengirisan terlalu tebal membuat bahan tidak mudah kering dan lebih cepat terkontaminasi oleh mikrobia sehingga mempengaruhi kualitas. Jika terlalu tipis akan mudah patah dan mengurangi kandungan bahan aktif.

Tahap pemanasan dan pengeringan dilakukan menggunakan cahaya matahari dan oven dengan mempertahankan suhu konstan dalam waktu tertentu. Suhu pengeringan yang digunakan adalah suhu ruang sesuai dengan cahaya matahari dan suhu dalam oven sebesar $30{ }^{\circ} \mathrm{C}, 40{ }^{\circ} \mathrm{C}, 50{ }^{\circ} \mathrm{C}$, $60^{\circ} \mathrm{C}$ dan $70^{\circ} \mathrm{C}$ selama $1,2,3,16,24,48$ dan 72 jam. 


\section{HASIL DAN PEMBAHASAN}

Sterilisasi pemanasan untuk memperoleh kualitas simplisia kunyit yang baik dilakukan menggunakan sinar matahari dan pengeringan menggunakan alat. Hasil pengeringan antara tanaman obat yang dikeringkan menggunakan oven diperlihatkan pada Gambar 1. Pengeringan menggunakan sinar matahari membutuhkan waktu lebih dari satu minggu agar didapatkan hasil yang benar-benar kering. Disisi lain, pengeringan menggunakan alat pada suhu $70^{\circ} \mathrm{C}$ selama 3 hari menghasilkan simplisia yang terlalu kering.

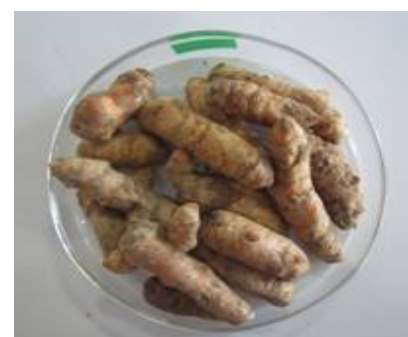

1

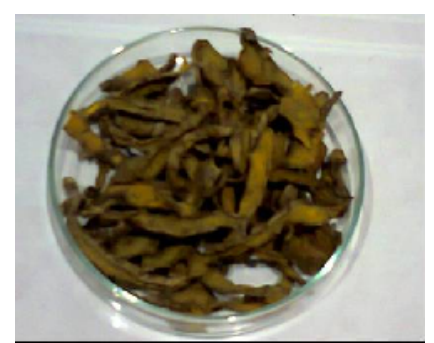

2

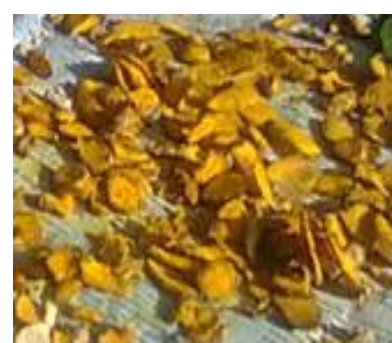

3

Gambar 1. Kunyit (1) dan hasil pengeringan dengan oven (2) serta sinar matahari (3)

Proses pengeringan untuk menghasilkan kualitas simplisia kunyit yang optimal menggunakan variasi suhu dan lama waktu pengeringan memperlihatkan penurunan pertumbuhan mikroorganisme. Hasil proses pengeringan yang diperoleh dan inkubasi pada suhu ruang selama 1 - 48 jam pada suhu 30 $60{ }^{0} \mathrm{C}$ memperlihatkan pertumbuhan jamur yang sangat intensif pada pengeringan suhu $30-60{ }^{\circ} \mathrm{C}$ selama 1-16 jam. Inkubasi selama 24 - 48 jam mulai memperlihatkan penurunan pertumbuhan jamur pada suhu $50^{\circ} \mathrm{C}$ selama 48 jam, suhu $60^{\circ} \mathrm{C}$ selama 16 jam. Sedangkan pemanasan menggunakan suhu $70^{\circ} \mathrm{C}$ selama 48 - 72 jam telah membuat simplisia tidak ditumbuhi jamur walaupun telah disimpan selama 3 bulan, namun simplisia sangat kering dan kandungan zat aktif didalamnya berpotensi mengalami penurunan kualitas. Pengeringan simplisia yang dilakukan menggunakan sinar matahari, oven, blower atau fresh dryer juga umumnya dilakukan pada suhu $30-50^{\circ} \mathrm{C}$. agar mutunya tidak menurun (Balai Penelitian Tanaman Obat dan Obat Tradisional, 2007).

Hasil penjemuran menggunakan alat yang ditambah blower dan kompor gas dapat dilakukan pada suhu $40-50^{\circ} \mathrm{C}$ dan membutuhkan waktu lebih singkat yaitu sekitar 8 - 10 jam. Bila hanya menggunakan sinar matahari akan membutuhkan waktu lebih dari 1 minggu.

Hasil pengamatan kualitas berdasarkan pertumbuhan mikrobia pada cawan metri pada media jamur (PDA) dan media bakteri (NA) memperlihatkan tumbuhnya beberapa jenis mikrobia yang didominasi oleh jamur dilihat dari keberadaan miselia, seperti terlihat pada Gambar 2 dan Gambar 3. Beberapa peneliti menyatakan bahwa mikrobia yang sering mencemari simplisia tanaman obat umumnya merupakan anggota genus Penicillium, Mucor, Rhizopus, dan Aspergillus. Sedangkan bakteri yang menjadi kontaminan simplisia adalah Escherichia coli dan Coliforms (Imandel dan Adibnia, 2000; Pundir dan Jain, 
2000; Stević et al., 2012). Meskipun demikian kandungan zat aktif dalam ekstrak kunyit diperkirakan tidak mengalami perubahan. Senyawa kimia kunyit berupa tanin, polifenol, poliasetilen, flavonol, sterol dan alkaloid akan menekan memperlambat dan menghambat pertumbuhan sejumlah mikrobia (Ivanovska, 1996; Darout et al., 2000). Periode inkubasi juga mempengaruhi jumlah dan jenis jamur yang tumbuh. Kandungan senyawa aktif kunyit juga akan menghambat pertumbuhan bakteri E. coli, S. aureus, Bacillus dan $P$. aeruginosa.

Hasil pengamatan terhadap pertumbuhan jamur dan bakteri pada suhu inkubasi $30{ }^{\circ} \mathrm{C}$ $40^{\circ} \mathrm{C}$ selama $1-16$ jam memperlihatkan bahwa simplisia kunyit tidak kehilangan kandungan air dalam jumlah besar sehingga cukup untuk melarutkan senyawa aktif yang dalam air yang menghambat pertumbuhan jamur dan mikrobia. Inkubasi pada waktu yang lebih lama akan mengurangi hambatan pertumbuhan mikrobia, Selain itu suhu pemanasan Jamur tumbuh dengan subur dan baru terhambat lagi pada suhu. Inkubasi simplisia kunyit pada suhu $50^{\circ} \mathrm{C}$ sampai 24 jam akan membuat pertumbuhan mikrobia khususnya jamur tidak lagi tertekan oleh senyawa aktif yang terlarut dalam air. Sedangkan suhu $60^{\circ} \mathrm{C}$ selama 16 jam dan seterusnya akan menghambat pertumbuhan mikrobia, namun patut diperhatikan bahwa inkubasi lebih lama senderung menurunkan kualitas simplisia. Pengeringan dapat menyebabkan perubahan-perubahan hidrolisa enzimatis, perubahan warna menjadi coklat, fermentasi dan oksidasi. Ciri-ciri waktu pengeringan sudah berakhir apabila simplisia dapat dipatahkan dengan mudah dengan kadar air $\pm 8-10 \%$. Kualitas simplisia dengan kadar air tersebut cukup baik untuk pengolahan lebih lanjut dan penyimpanan.
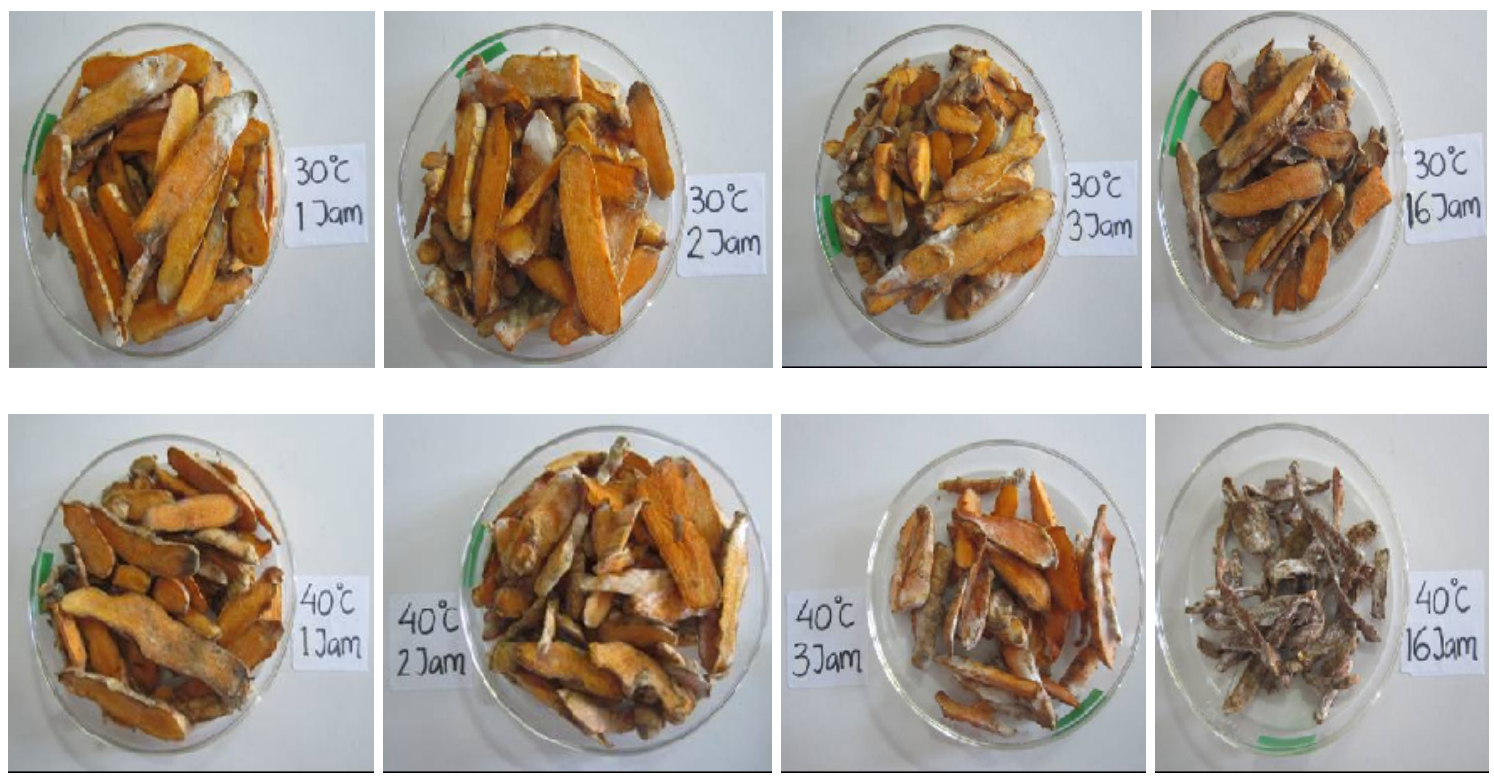

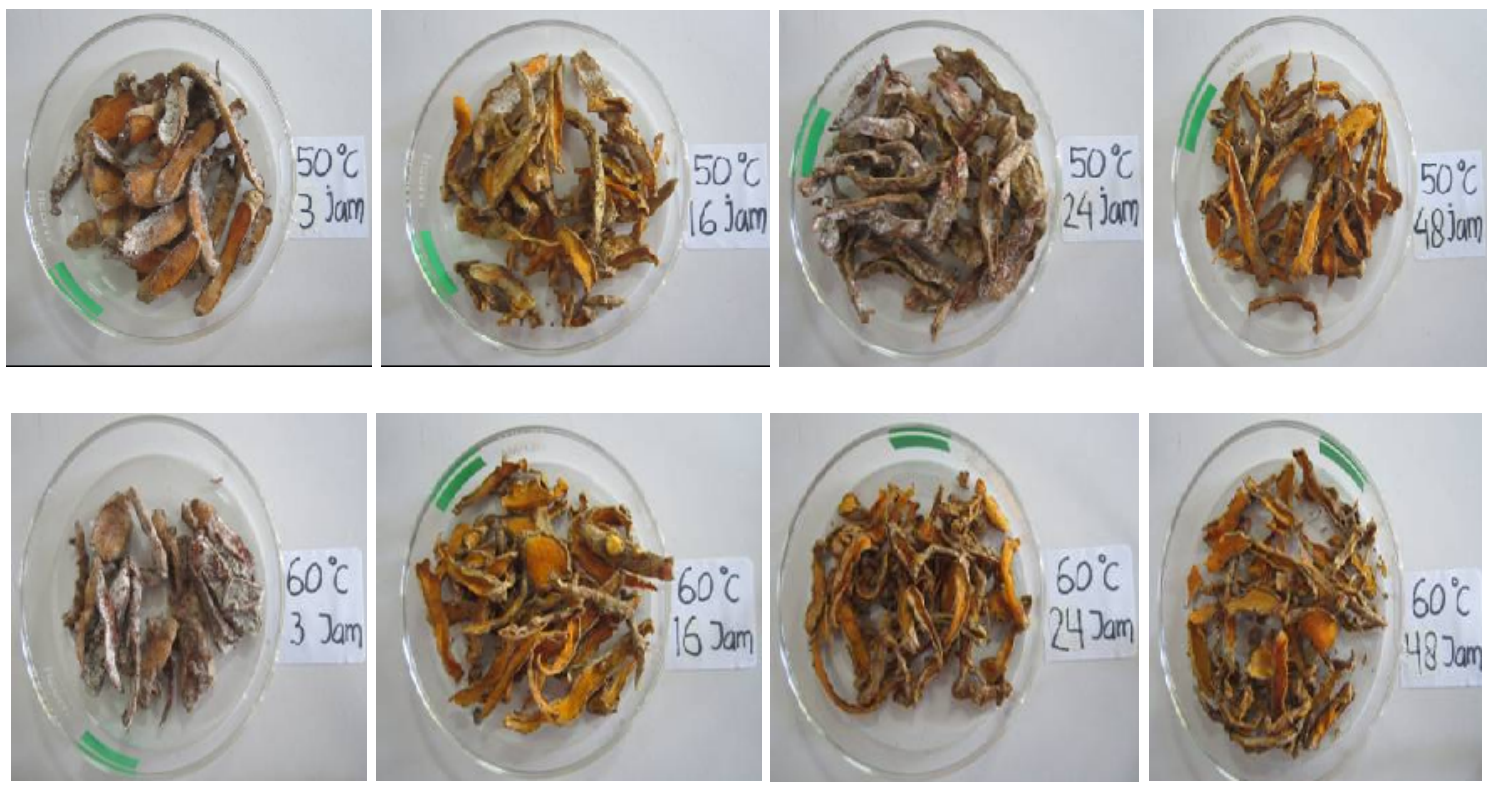

Gambar 2. Inkubasi simplisoia pada alat pengering pada suhu dan waktu bervariasi

Simplisia kunyit yang telah mengalami proses pengeringan selama periode waktu yang bervariasi antara 1- 48 jam telah ditumbuhkan pada medium pertumbuhan untuk jamur dan bakteri. Hasil pengamatan pada Gambar 3. memperlihatkan bahwa suhu $50^{\circ} \mathrm{C}-60^{\circ} \mathrm{C}$ selama $24-48$ jam telah menghambat pertumbuhan bakteri, namun tidak menghambat pertumbuhan jamur. $\begin{array}{ccr}\text { Secara } & \text { keseluruhan } & \text { pengolahan } \\ \text { simplisia } & \text { kunyit yang } & \text { diperoleh }\end{array}$ memperlihatkan bahwa suhu dan lamanya waktu inkubasi sangat mempengaruhi jumlah dan jenis kontaminan yang pada akhirnya berpengaruh terhadap kualitas. Simplisia tanaman obat lain akan membutuhkan waktu inkubasi dan suhu yang berbeda pula untuk menghasilkan simplisia yang berkualitas dan tidak merusak senyawa aktif di dalamnya.
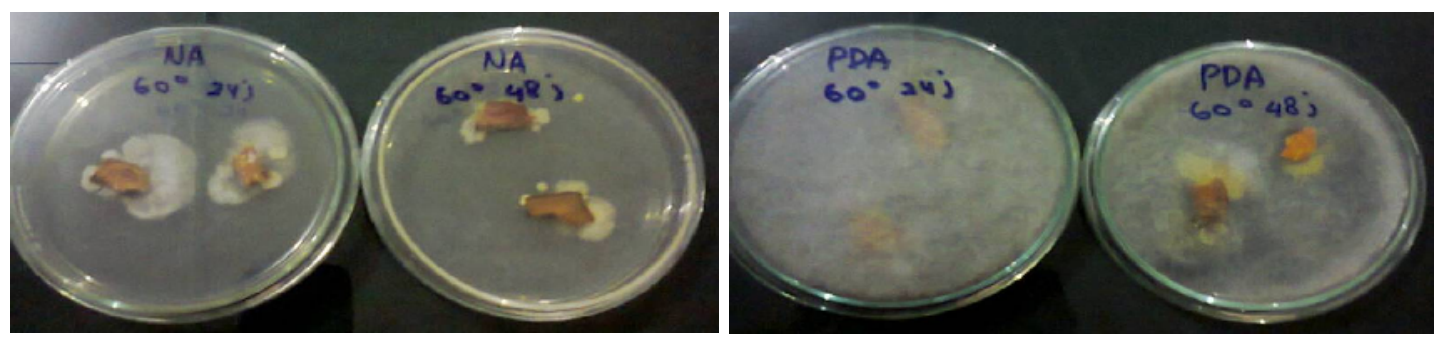

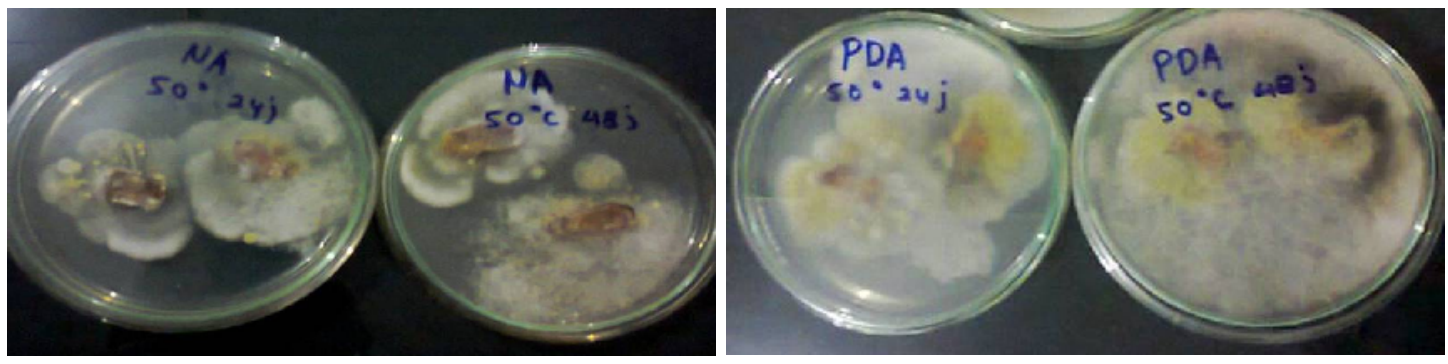

Gambar 3. Inkubasi simplisia pada alat pengering pada suhu dan waktu bervariasi

Pengetahuan petani setelah penyuluhan tentang sterilisasi dan pengamatan kualitas simplisia telah menambah pemahaman mereka akan pentingnya proses tersebut dalam pengolahan simplisia kunyit dan tanaman obat lainnya. Sterilisasi panas menggunakan suhu dan waktu yang tepat memperlihatkan penurunan kontaminasi mikrobia.

\section{KESIMPULAN}

Hasil pemanasan memperlihatkan bahwa suhu $50^{\circ} \mathrm{C}$ selama 48 jam menghasilkan produk simplisia C. domestica terbaik. Mikrobia kontaminan tidak dijumpai setelah pemanasan pada suhu $60^{\circ} \mathrm{C}$ selama $16-48$ jam setelah penyimpanan 3 bulan.

\section{UCAPAN TERIMAKASIH}

Terimakasih pada Ditlitabmas Ditjen Dikti Kemendikbud yang telah membiayai kegiatan pengabdian masyarakat ini melalui DIPA UNDIP No : 023.04.02. $1891 \quad 85$ /2014 tanggal 05 Desember 2013

\section{DAFTAR PUSTAKA}

Ahmad, M. 2013. Protective effects of curcumin against lithium-pilocarpine induced status epilepticus, cognitive dysfunction and oxidative stress in young rats. Original article. Saudi Journal of Biological Sciences.20:155-162

Badan Standardisasi Nasional. 2005. SNI 01-70852005 Standar Simplisia Kunir.

Balai Penelitian Tanaman Obat dan Obat Tradisional (Balittro). 2007. Teknologi Penyiapan Simplisia terstandar tanaman obat, Balai tanaman obat dan obat. Sumber: Bagem Sembiring, Warta Puslitbangbun (13)2.

Darout IA, Christy AA. Skaug N. 2000. Identification and quantification of some potentially antimicrobial anionic components in miswak extract. Indian J. of Pharmacology 2000; 32: 11-14

Ferreira F. D. , C. Kemmelmeier., C.C. Arrotéia, C.L. da Costa, C. A. Mallmann, V. Janeiro., F. M.D. Ferreira, S. A. G. Mossini, E. L Silva, and M. Machinski Jr. 2013. Inhibitory effect of the essential oil of Curcuma longa L. and curcumin on aflatoxin production by Aspergillus flavus Link. Food Chemistry 136:789-793

Imandel K dan Adibnia H. 2000. Microbial contamination of spices (turmeric, black pepper, and sumac) in western part of Tehran. Iranian J.l of Public health 29(14):37-44.

Ivanovska $\mathrm{N}$, Philipov $\mathrm{S}$, Istatkova $\mathrm{R}$ and Georgieva P. 1996. Antimicrobial and immunological activity of ethanol extracts and fractions from Isopyrum thalictroides. $J$. Ethnopharmacol., 54: 14-15.

Kösslera S, Nofzigera C, Jakabb M, Dossenaa S, and Paulmichla M. 2012. Curcumin affects cell survival and cell volume regulation in human renal and intestinal cells. Toxicology. 292 : 123-135

Mateblowski, M. 1991. Curcuma xanthorrhiza Roxb, penerbit PMI Verlag, ISBN 3-89119173-1, ISBN 978-3-89119-173-6, halaman 36

Pundir R.K. and Jain P. 2010. Comparative studies on the antimicrobial activity of black pepper 
(piper nigrum) and turmeric (Curcuma longa) extracts. International J. of Appl Biology and Pharmaceutical Technology www.ijabpt.com ISSN 0976-4550. I(2):491

Stević T, Pavlović S, Stanković S and Savikin K. 2012. Pathogenic microorganisms of medicinal herbal drugs Arch. Biol. Sci.,
Belgrade, DOI:10.2298/ABS1201049S. 64 (1): 49-58

Trujillo J, Chirino Y I, Molina-Jijón E, AndéricaRomero AC , Tapia ET and PedrazaChaverrí J. 2013. Renoprotective effect of the antioxidant curcumin : Recent findings. Mini Review. Redox Biology. p. 448-456 